\title{
Biochemical Study of the Effects of Insulin Resistance on Sex Hormones in Men and Women Type-2 Diabetic Patients I Meisan-Iraq
}

\author{
Adnan Jassim Mohammed Al-Fartosy", Ibrahim Majar Mohammed \\ Department of Chemistry, College of Science, University of Basra, Basra, Iraq \\ Email address: \\ dr.adnanfrtosy@yahoo.com (A. J. M. Al-Fartosy) \\ ${ }^{*}$ Corresponding author
}

\section{To cite this article:}

Adnan Jassim Mohammed Al-Fartosy, Ibrahim Majar Mohammed. Biochemical Study of the Effects of Insulin Resistance on Sex Hormones in Men and Women Type-2 Diabetic Patients / Meisan-Iraq. Advances in Biochemistry. Vol. 5, No. 5, 2017, pp. 79-88. doi: 10.11648/j.ab.20170505.11

Received: August 12, 2017; Accepted: August 28, 2017; Published: September 12, 2017

\begin{abstract}
Obesity, a case accompanied by increased insulin resistance, is associated with low follicle stimulating hormone, luteinizing hormone, total testosterone and progesterone and estradiol levels. As there is no scientific report on diabetes complications and its effects on type 2 diabetic patients in the province of Meisan (southern of Iraq), the present investigation was done to evaluate the levels of body mass index, insulin resistance and the levels of sex hormones in serum of both men and women type 2 diabetic patients. Data obtained in the present study, show a significant increase in insulin resistance level (4.24 \pm 0.57 Vs. $1.36 \pm 0.23$ and $4.31 \pm 0.59$ Vs. $1.18 \pm 0.13, \mathrm{P}<0.05)$ respectively, in men and women type 2 diabetic patients compared to control. Also, the present study show a significant decrease in follicle stimulating hormone level $(7.24 \pm 1.14 \mathrm{Vs}$. $12.79 \pm 0.87$ and $38.14 \pm 4.44$ Vs. $54.16 \pm 3.64, \mathrm{P}<0.05)$, a significant decrease in luteinizing hormone level $(5.32 \pm 0.74$ Vs. $7.54 \pm 1.27$ and $30.12 \pm 4.20$ Vs. $43.33 \pm 2.07, \mathrm{P}<0.05)$, a significant decrease in testosterone level $(4.69 \pm 0.92$ Vs. $8.20 \pm 2.2$ and $0.57 \pm 0.11$ Vs. $0.69 \pm 0.21, \mathrm{P}<0.01)$, a significant decrease in progesterone level $(0.25 \pm 0.03$ Vs. $0.42 \pm 0.10$ and $0.30 \pm$ 0.04 Vs. $0.46 \pm 0.12, \mathrm{P}<0.05)$ and a significant decrease in estradiol level $(25.04 \pm 3.35$ Vs. $33.80 \pm 8.4$ and $34.33 \pm 4.21$ Vs. $41.42 \pm 5.64, \mathrm{P}<0.05)$ respectively, in men and women type 2 diabetic patients compared to control. In conclusion, the findings further demonstrated that insulin resistance plays an important role in the pathogenesis of many human diseases, such as diabetes, obesity, and reduction of fertility. Therefore, the associated of obesity and increased insulin resistance is accompanied by low levels of follicle stimulating hormone, luteinizing hormone, testosterone, progesterone and estradiol in both men and women.
\end{abstract}

Keywords: Insulin Resistance, Obesity, Sex Hormones, Type 2 Diabetes Mellitus

\section{Introduction}

The term diabetes mellitus describes a metabolic disorder of multiple etiologies and it is a group of metabolic diseases in which a person has high blood sugar, either because the pancreas does not produce enough insulin, or because cells do not respond to the insulin that is produced. This high blood sugar produces the classical symptoms of polyuria (frequent urination), polydipsia (increased thirst) and polyphagia (increased hunger) [1]. Diabetes mellitus is characterized by chronic hyperglycaemia with disturbances of carbohydrate, fat and protein metabolism resulting from defects in insulin secretion, insulin action, or both.

The effects of diabetes mellitus include long-term damage, dysfunction and failure of various organs. In its most severe forms, ketoacidosis or a non-ketotic hyperosmolar state may develop and lead to stupor, coma and, in absence of effective treatment, death [2]. Insulin resistance is defined as the impaired ability of cells to response to the action of insulin in transporting glucose (sugar) from the bloodstream into muscle and tissues. In humans, insulin resistance develops with obesity and type 2 diabetes mellitus [3]. Type 2 diabetes 
(non-insulin dependent diabetes) is characterized by insulin resistance and is usually linked with abnormality in secretion of insulin. Generally, about $90-95 \%$ of cases of diabetes are of this type of diabetes [4]. Obesity increase resistance to the cellular actions of insulin, characterized by losing the ability of insulin to inhibit glucose output from the liver and to promote glucose uptake in fat and muscle [5].

The association between obesity and insulin resistance is likely a cause and effect relationship since human and animal studies indicate a directly proportional between weight and insulin sensitivity [6]. It has been suggested that the inverse correlation between testosterone and insulin resistance is due to obesity [7]. Given that the latter is associated with both insulin resistance and low levels of sex hormone-binding globulin. If this hypothesis is correct, the reducing in levels of testosterone seen with increasing obesity level in men should be referenced by low levels of sex hormone-binding globulin alone, and the free testosterone should be normal. However, many studies have shown that total and free testosterone levels reduced in proportion to the level of obesity [8]. The recent reports indicate that obese males have a reduction in sperm quality, and cause particular changes in shape and molecular structure of germ cells in the testis and mature sperms [9]. Male obesity usually expresses a unique hormonal profile described as "hypogonadotropic hyperestrogenic hypogonadism". Both total and free testosterone levels are reduced in obese males. Total body fat content, subcutaneous fat, and intra-abdominal fat have been associated with reduction in levels of total and free testosterone [7]. Central obesity in particular appears to be associated with a decrease in levels of circulating androgen directly proportional to the degree of obesity [10].

As there is no scientific report on diabetes complications and its effects on type 2 diabetic patients in Meisan province (southern of Iraq), the present investigation was done to evaluate the levels of body mass index, insulin resistance and the levels of sex hormones in serum of both men and women type 2 diabetic patients.

\section{Materials and Methods}

\subsection{Subjects}

This study was carried out on peoples who suffering from type II of diabetes mellitus in Meisan province. The study samples included (50) patients suffering from type II of diabetes (26 men and 24 women) aged between (37) and (65) years, and controlled with (50) healthy individuals (25 men and 25 women) aged between (36) and (65) years. Standard self-administered questionnaires were used to define age, duration of diabetes, health habits (smoking, alcohol consumption and exercise), medical history and current medications. Individuals should not belong to the class of secondary diabetes due to pancreatic diseases, hormonal abnormalities, drug induced, genetic syndromes and those who used exogenous hormone, opium or medication which might affect sex hormone level were excluded from the study...etc. The control group was health Individuals; not suffering from type-2 diabetes nor having any family history of type-2 diabetes mellitus; not suffering from any acute or chronic cardiovascular diseases; not taking any drug believed to alter plasma glucose level.

\subsection{Samples}

The studied samples of patients were collected from the central laboratory of Al- Sadder General Hospital and Diabetes and Endocrine Center at the province of Meisan. All blood samples were obtained in the morning between 08:00 and 09:00 hours after a 12-h fast and a 30-min of rest in the supine position. Blood samples were collected from the antecubital vein. Rubber tourniquet was applied for less than one minute and the site to be punctured cleaned with $70 \%$ methylated spirit. A single blood sample was collected from each subject. About $10 \mathrm{ml}$ of blood was taken. All tests were performed on serum, some of the blood samples were allowed to clot on ice, and then centrifuged (402 Xg for 10 minutes) to be used serum samples immediately for detection of variable in this study, and others were stored in deep freezing at $\left(-20^{\circ} \mathrm{C}\right)$ until using.

\subsection{Methods}

\subsubsection{Body Mass Index (BMI)}

Body mass index was calculated as weight in kilograms divided by height in meters squared using the following formula: Body Mass Index $\left(\mathrm{kg} / \mathrm{m}^{2}\right)=\mathrm{Wt}$ in $\mathrm{kg} / \mathrm{Ht}$ in $\mathrm{m}^{2}$

Height and weight were measured by using a regularly calibrated stadiometer and balance-beam scale with participants wearing light clothing and no shoes.

\subsubsection{Measurement of Insulin Resistance Parameters}

Insulin resistance parameters (insulin resistance (HOMA2IR), beta cell activity (HOMA\%B) and insulin sensitivity $(\mathrm{HOMA} \% \mathrm{~S})$ ) were calculated from fasting insulin and fasting blood glucose using homeostatic model assessment (HOMA2) calculator software.

\subsubsection{Methods of Biochemical Estimation}

The control and diabetic patients (type II) blood samples were analyzed for biochemical parameters by standard procedures as follows: Serum glucose was estimated by kit (Randox/England) [11], serum insulin was estimated by kit (demeditec/Germany) [12], serum C-Peptide was estimated by kit (demeditec/Germany) [13] and serum follicle stimulating hormone [14], luteinizing hormone [15], testosterone [16], progesterone [17] and estradiol [18] was estimated by direct method using reagent kit (Human/Germany).

\subsubsection{Statistical Analysis}

The data were expressed as the mean values $\pm \mathrm{SD}$, and tested with analysis of variance followed by Dunnett's t-test. P- values $<0.05,0.01$ were considered to be statistically significant. 


\section{Results}

\subsection{Basic Characteristics of Individuals in the Study}

A total of 100 subjects were included in the present study. 50 patients with type 2 diabetic patients and 50 healthy individuals considered as control group. The general characteristics of all subjects participated in the present study were presented in Table 1.

Table 1. The demographic characteristics of the study.

\begin{tabular}{|c|c|c|c|}
\hline \multicolumn{2}{|c|}{ The characteristics } & Healthy control & Type 2 DM. \\
\hline \multicolumn{2}{|l|}{ Total (No.) } & 50 & 50 \\
\hline \multicolumn{2}{|c|}{ Age $($ mean \pm SD) } & $51.66 \pm 7.72$ & $52.37 \pm 6.46$ \\
\hline \multirow{2}{*}{ Sex } & Male & 25 & 26 \\
\hline & Female & 25 & 24 \\
\hline \multirow{2}{*}{$\begin{array}{l}\text { DM. duration } \\
(\text { mean } \pm \text { SD) }\end{array}$} & $\leq 10$ & & 32 \\
\hline & $>10$ & & 18 \\
\hline \multirow{2}{*}{ Smoking habit } & Negative & 26 & 49 \\
\hline & Positive & 4 & 1 \\
\hline
\end{tabular}

\subsection{Body Mass Index (BMI) in Type 2 Diabetic Patients}

In patients where body mass index as a clinical parameter that can be used to determine the extent of glycemic control. Table 2 and Figure 1 clearly showed that in diabetic patients group, body mass index was found to be significantly higher (men vs. women respectively, $\mathrm{P}<0.01$ ) compared to controls, and a significant differences were observed in body mass index between the men and women patients groups $(\mathrm{P}<0.01)$.

Table 2. Body Mass Index (BMI) in men and women of control and patients with type 2 diabetes mellitus. The values are the Mean $\pm S D$.

\begin{tabular}{|c|c|c|c|c|c|}
\hline & \multicolumn{2}{|c|}{ Type 2 DM } & \multicolumn{2}{|c|}{ Healthy control } & \multirow{2}{*}{$\begin{array}{l}\text { Significance } \\
\text { p-value }\end{array}$} \\
\hline & Men & Women & Men & Women & \\
\hline $\begin{array}{l}\text { BMI } \\
\mathrm{kg} / \mathrm{m}^{2}\end{array}$ & $\begin{array}{l}25.49 \pm \\
1.34\end{array}$ & $\begin{array}{l}26.51 \pm \\
2.562\end{array}$ & $\begin{array}{l}21.35 \pm \\
1.54\end{array}$ & $\begin{array}{l}22.54 \pm \\
2.75\end{array}$ & HS \\
\hline
\end{tabular}

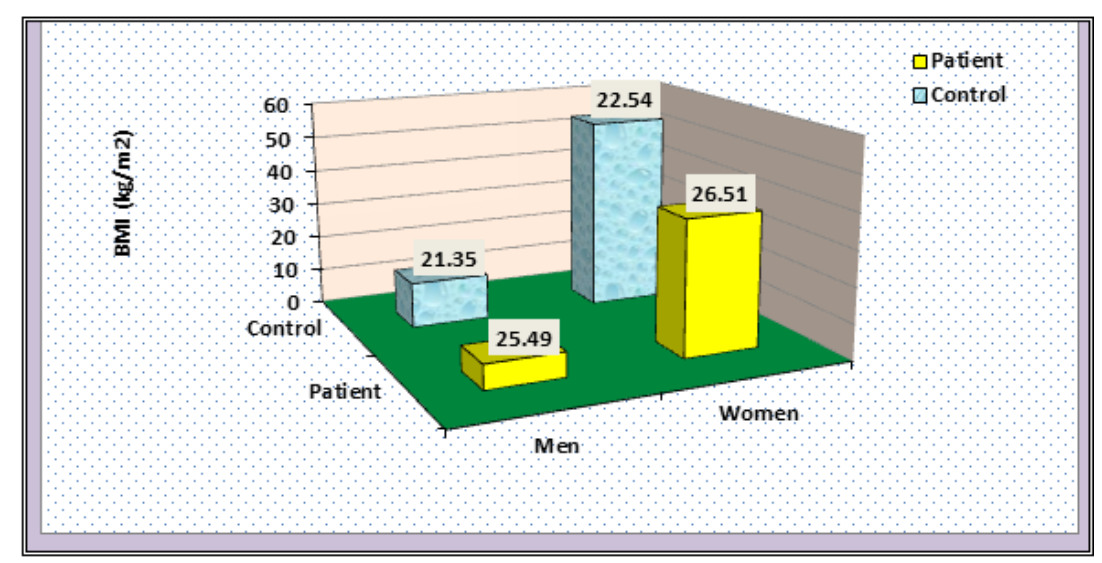

Figure 1. Body Mass Index (BMI) in men and women of control and patients with type 2 diabetic patients.

\subsection{Study the Insulin Resistance Parameters}

Data obtained in the present study, show a significant increase in insulin resistance level $(4.24 \pm 0.57 \mathrm{Vs} .1 .36 \pm 0.23$ and $4.31 \pm 0.59$ Vs. $1.18 \pm 0.13, \mathrm{P}<0.05)$ respectively, in men and women type 2 diabetic patients compared to control. Also, Insulin/ Glucose ratio was significantly $(\mathrm{P}<0.05)$ higher in men and women type 2 diabetic patients compared to control (0.152 Vs. 0.093 and 0.164 Vs. 0.083, respectively). Furthermore, there was no significant difference between HOMA $\% \mathrm{~B} \pm$ level of cases and controls. Moreover, level of $\mathrm{HOMA} \% \mathrm{~S} \pm$ was significantly lower in cases compared to controls, as shown in Table 3.

Table 3. Study the Insulin Resistance Parameters. The values are the Mean $\pm S D$.

\begin{tabular}{lllll}
\hline & Type 2 DM & & Healthy Control & women \\
\hline Parameters & men & women & men & Significance p-value \\
\hline Glucose $(\mathrm{mg} / \mathrm{dl})$ & $189.42 \pm 15.18$ & $180.21 \pm 16.33$ & $108 \pm 9.2$ & $106 \pm 8.3$ \\
Insulin $(\mu \mathrm{u} / \mathrm{ml}) \pm \mathrm{SD}$ & $28.85 \pm 3.77$ & $29.65 \pm 4.06$ & $10.08 \pm 1.66$ & $8.81 \pm 0.99$ \\
Insulin/ Glucose & 0.152 & 0.164 & 0.093 & 0.083 \\
HOMA2IR \pm SD & $4.24 \pm 0.57$ & $4.31 \pm 0.59$ & $1.36 \pm 0.23$ & $1.18 \pm 0.13$ \\
HOMA\%B \pm & $62.0 \pm 2.39$ & $69.50 \pm 2.24$ & $75.57 \pm 13.1$ & $85.05 \pm 9.19$ \\
HOMA\%S \pm & $23.60 \pm 3.90$ & $23.20 \pm 3.70$ & $80.80 \pm 12.46$ & $\mathrm{~S}$ \\
\hline
\end{tabular}

\subsection{Levels of Serum Glucose, Insulin Hormone and C-Peptide}

Results in (Table 4) show a highly significantly increases in serum glucose level $(185 \pm 16.288$ Vs. $107 \pm 9.52 \mathrm{mg} / \mathrm{dl}, \mathrm{P}$
$<0.01$ ) in type 2 diabetes mellitus subjects compared to control. Also, there was a significant increase in serum insulin hormone level $(29.15 \pm 5.51$ Vs. $9.70 \pm 1.59 \mu \mathrm{U} / \mathrm{ml}, \mathrm{P}$ $<0.01)$ in type 2 diabetes mellitus subjects compared to control. Same (Table 4) reflects the level of serum C-peptide 
(14.95 \pm 0.64 Vs. $3.16 \pm 1.35 \mathrm{ng} / \mathrm{ml}$, respectively) with their significant increase $(\mathrm{P}<0.01)$ in type 2 diabetes mellitus subjects compared with control.

Table 4. Levels of serum glucose, insulin hormone and C-peptide in control and patients with type 2 diabetes mellitus. The values are the Mean \pm SD.

\begin{tabular}{|c|c|c|c|c|c|c|c|}
\hline & & \multicolumn{2}{|c|}{ Glucose (mg/dl) } & \multicolumn{2}{|c|}{ C-Peptide (ng/ml) } & \multicolumn{2}{|c|}{ Insulin Hormone $(\mu \mathrm{U} / \mathrm{ml})$} \\
\hline & & \multicolumn{2}{|c|}{ Men and Women } & \multicolumn{2}{|c|}{ Men and Women } & \multicolumn{2}{|c|}{ Men and Women } \\
\hline & & $\begin{array}{l}\text { Diabetic } \\
(50)\end{array}$ & $\begin{array}{l}\text { Control } \\
(50)\end{array}$ & $\begin{array}{l}\text { Diabetic } \\
(50)\end{array}$ & $\begin{array}{l}\text { Control } \\
(50)\end{array}$ & $\begin{array}{l}\text { Diabetic } \\
(50)\end{array}$ & $\begin{array}{l}\text { Control } \\
(50)\end{array}$ \\
\hline Mean \pm SD & & $185 \pm 16.28$ & $107 \pm 9.52$ & $14.95 \pm 0.64$ & $3.16 \pm 1.35$ & $29.15 \pm 5.51$ & $9.70 \pm 1.59$ \\
\hline SE & & 2.30 & 1.34 & 0.09 & 0.19 & 0.78 & 0.22 \\
\hline Range & & $150-215$ & $86-124$ & $11.89-15.92$ & $1.40-4.96$ & $18.96-35.31$ & $7.10-14.2$ \\
\hline $05 \% \mathrm{CJ}$ & Lower & 153.0912 & 88.3408 & 13.6956 & 0.514 & 18.3504 & 6.5836 \\
\hline $\mathrm{P}$-value & & HS & & HS & & HS & \\
\hline
\end{tabular}

\subsection{Results of Endocrinological Assay}

\subsubsection{Level of Follicle Stimulating Hormone and Luteinizing Hormone in Control and Type 2 Diabetic Patients}

This study showed, a significant decreases $(\mathrm{P}<0.05)$ was seen in serum follicle stimulating hormone in type 2 diabetes mellitus subjects $(7.24+1.14 \mu \mathrm{U} / \mathrm{ml})$ in men and $(38.14 \pm$
$4.44 \mu \mathrm{U} / \mathrm{ml})$ in women compared with that of control were $(12.79 \pm 0.87 \mu \mathrm{U} / \mathrm{ml})$ in men and $(54.16 \pm 3.64 \mu \mathrm{U} / \mathrm{ml})$ in women and a significant decreases $(\mathrm{P}<0.05)$ was seen in serum luteinizing hormone in type 2 diabetes mellitus subjects $(5.32 \pm 0.74)$ in men and $(30.12 \pm 4.20 \mu \mathrm{U} / \mathrm{ml})$ in women compared with that of control were $(7.54 \pm 1.27$ $\mu \mathrm{U} / \mathrm{ml})$ in men and $(43.33 \pm 2.07 \mu \mathrm{U} / \mathrm{ml})$ in women, as shown in (Table 5) and (Figures $2 \& 3$ ), respectively.

Table 5. Levels of serum follicle stimulating hormone and luteinizing hormone in men and women of control and patients with type 2 diabetes mellitus. The values are the Mean $\pm S D$.

\begin{tabular}{|c|c|c|c|c|c|c|c|c|c|}
\hline & & \multicolumn{4}{|c|}{ Follicle stimulating hormone $(\mu \mathrm{U} / \mathrm{ml})$} & \multicolumn{4}{|c|}{ Luteinizing hormone $(\mu \mathrm{U} / \mathrm{ml})$} \\
\hline & & \multicolumn{2}{|c|}{ Diabetes } & \multicolumn{2}{|l|}{ Control } & \multicolumn{2}{|c|}{ Diabetes } & \multicolumn{2}{|l|}{ Control } \\
\hline & & $\begin{array}{l}\text { Men } \\
(26)\end{array}$ & $\begin{array}{l}\text { Women } \\
(24)\end{array}$ & $\begin{array}{l}\text { Men } \\
(25)\end{array}$ & $\begin{array}{l}\text { Women } \\
(25)\end{array}$ & $\begin{array}{l}\text { Men } \\
(26)\end{array}$ & $\begin{array}{l}\text { Women } \\
(24)\end{array}$ & $\begin{array}{l}\text { Men } \\
(25)\end{array}$ & $\begin{array}{l}\text { Women } \\
(25)\end{array}$ \\
\hline \multicolumn{2}{|l|}{ Mean \pm SD } & $7.24 \pm 1.14$ & $38.14 \pm 4.44$ & $12.79 \pm 0.87$ & $54.16 \pm 3.64$ & $5.32 \pm 0.74$ & $30.12 \pm 4.20$ & $7.54 \pm 1.27$ & $43.33 \pm 2.07$ \\
\hline \multicolumn{2}{|c|}{ SE } & 0.22 & 0.90 & 0.14 & 0.94 & 0.14 & 0.85 & 0.21 & 0.53 \\
\hline \multicolumn{2}{|l|}{ Range } & $5.4-9.70$ & $32.10-47.20$ & $7.90-13.84$ & $44.0-69.9$ & $4.20-6.80$ & $23.30-38.10$ & $2.23-7.77$ & $39.13-46.6$ \\
\hline 95\% C.I & Lower & 5.0056 & 29.4376 & 11.0848 & 47.0256 & 3.8696 & 21.888 & 5.0508 & 39.2728 \\
\hline $\mathrm{P}$-value & & $\mathrm{S}$ & & & & $\mathrm{S}$ & & & \\
\hline
\end{tabular}

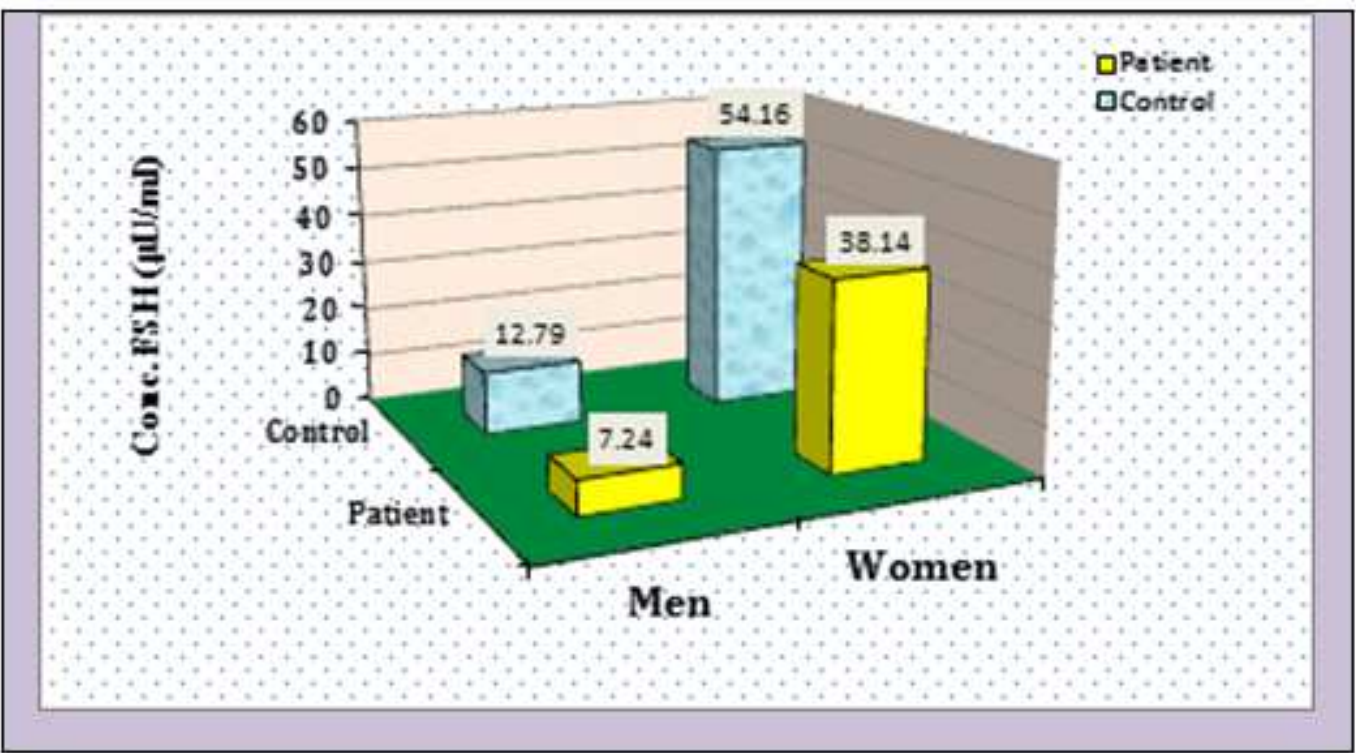

Figure 2. Level of FSH concentration in serum of healthy control and type 2 diabetic patients. 


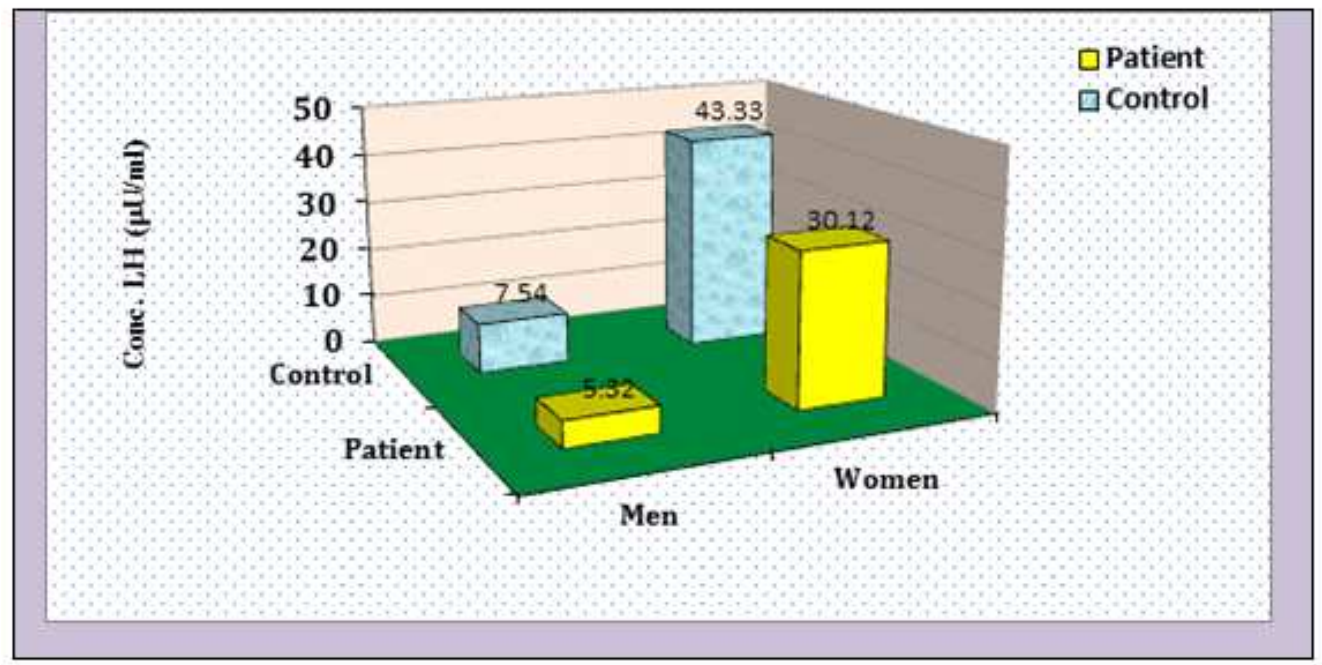

Figure 3. Level of LH concentration in serum of healthy control and type 2 diabetic patients.

\subsubsection{Level of Serum Testosterone Hormone in Control and Type 2 Diabetic Patients}

In this work (Table 6) and (Figure 4), there was a significant decreases $(\mathrm{P}<0.01)$ was seen in serum testosterone in type 2 diabetes mellitus subjects $(4.69 \pm 0.92 \mathrm{ng} / \mathrm{ml})$ in men and $(0.57 \pm 0.11 \mathrm{ng} / \mathrm{ml})$ in women compared with that of control were $(8.20 \pm 2.2 \mathrm{ng} / \mathrm{ml})$ in men and $(0.69 \pm 0.21 \mathrm{ng} / \mathrm{ml})$ in women.

Table 6. Levels of serum testosterone in men and women of control and patients with type 2 diabetes mellitus. The values are the Mean \pm SD.

\begin{tabular}{|c|c|c|c|c|c|}
\hline & & \multicolumn{4}{|c|}{ Testosterone (ng/ml) } \\
\hline & & \multicolumn{2}{|c|}{ Men } & \multicolumn{2}{|l|}{ Women } \\
\hline & & $\begin{array}{l}\text { Diabetic } \\
(26)\end{array}$ & $\begin{array}{l}\text { Control } \\
(25)\end{array}$ & $\begin{array}{l}\text { Diabetic } \\
(24)\end{array}$ & $\begin{array}{l}\text { Control } \\
(25)\end{array}$ \\
\hline \multicolumn{2}{|c|}{ Mean \pm SD } & $4.69 \pm 0.92$ & $8.20 \pm 2.2$ & $0.57 \pm 0.11$ & $0.69 \pm 0.21$ \\
\hline \multicolumn{2}{|c|}{ SE } & 0.81 & 0.56 & 0.02 & 0.05 \\
\hline \multicolumn{2}{|l|}{ Range } & $3.23-6.32$ & $3.8-9.9$ & $0.44-0.77$ & $0.28-0.92$ \\
\hline \multirow{2}{*}{$95 \%$ C.I } & Lower & 2.8868 & 3.888 & 0.3544 & 0.2784 \\
\hline & Upper & 6.4932 & 12.512 & 0.7856 & 1.1016 \\
\hline \multicolumn{2}{|c|}{ Significance p-value } & HS & & HS & \\
\hline
\end{tabular}

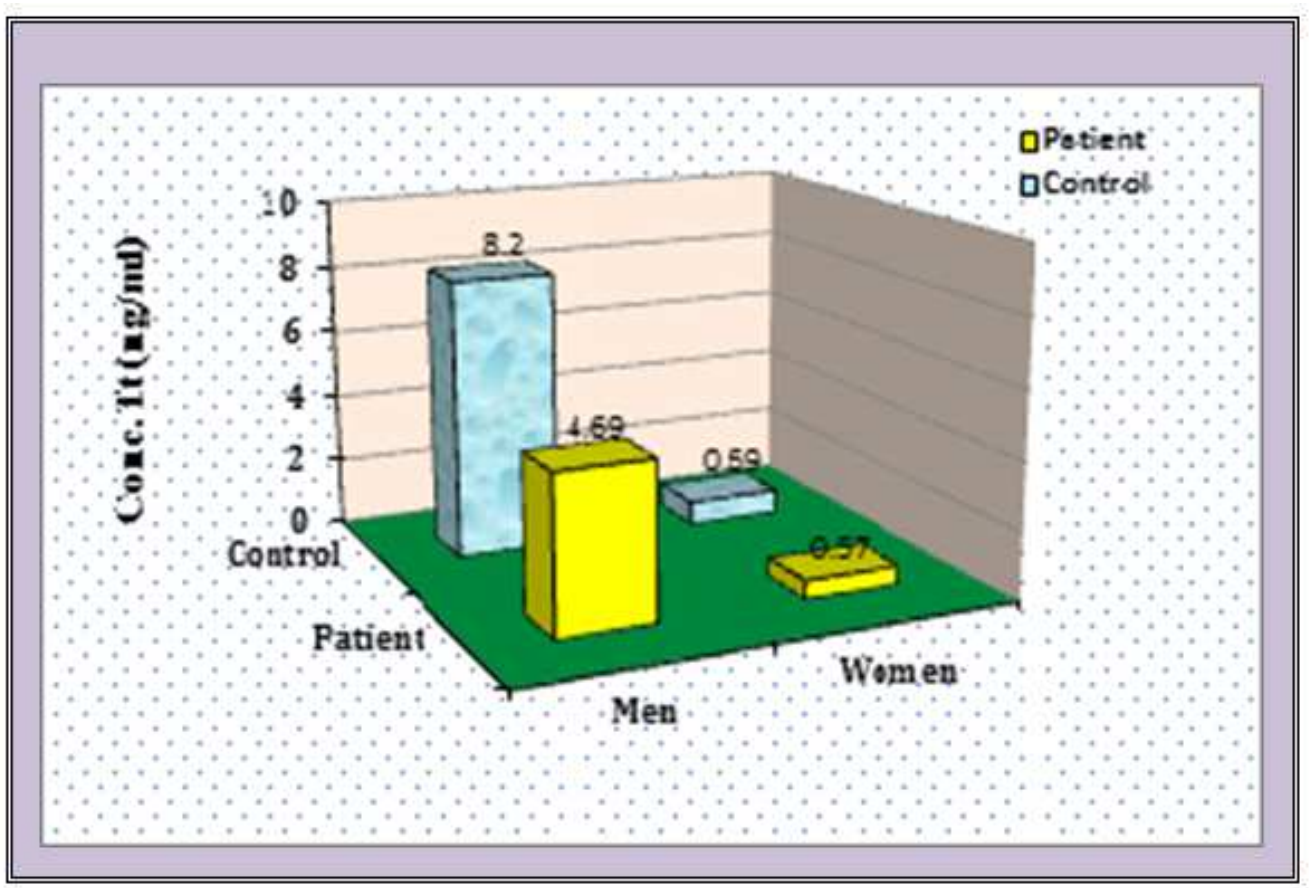

Figure 4. Level of testosterone hormone concentration in serum of healthy control and type 2 diabetic patients. 


\subsubsection{Level of Serum Progesterone Hormone in Control and Type 2 Diabetic Patients}

Data obtained in (Table 7) and (Figure 5), show a significant decreases $(\mathrm{P}<0.05)$ was seen in serum progesterone in type 2 diabetes mellitus subjects $(0.25 \pm 0.03$ $\mathrm{pg} / \mathrm{ml})$ in men and $(0.30 \pm 0.04 \mathrm{pg} / \mathrm{ml})$ in women compared with that of control were $(0.42 \pm 0.10 \mathrm{pg} / \mathrm{ml})$ in men and $(0.46 \pm 0.12 \mathrm{nk} / \mathrm{ml})$ in women.

Table 7. Levels of serum progesterone in men and women of control and patients with type 2 diabetes mellitus. The values are the Mean $\pm S D$.

\begin{tabular}{|c|c|c|c|c|c|}
\hline & & \multicolumn{4}{|c|}{ Progesterone (ng/ml) } \\
\hline & & \multicolumn{2}{|l|}{ Men } & \multicolumn{2}{|l|}{ Women } \\
\hline & & $\begin{array}{l}\text { Diabetic } \\
\text { (26) }\end{array}$ & $\begin{array}{l}\text { Control } \\
(25) \\
\end{array}$ & $\begin{array}{l}\text { Diabetic } \\
\text { (24) }\end{array}$ & $\begin{array}{l}\text { Control } \\
\text { (25) }\end{array}$ \\
\hline \multicolumn{2}{|c|}{ Mean \pm SD } & $0.25 \pm 0.03$ & $0.42 \pm 0.10$ & $0.30 \pm 0.04$ & $0.46 \pm 0.12$ \\
\hline \multicolumn{2}{|l|}{ SE } & 0.007 & 0.01 & 0.008 & 0.03 \\
\hline \multicolumn{2}{|l|}{ Range } & $0.18-0.32$ & $0.33-0.64$ & $0.24-0.39$ & $0.25-0.6$ \\
\hline \multirow{2}{*}{$95 \%$ C.I } & Lower & 0.1912 & 0.224 & 0.2216 & 0.2248 \\
\hline & Upper & 0.3088 & 0.616 & 0.3784 & 0.6952 \\
\hline \multicolumn{2}{|c|}{ Significance p-value } & $\mathrm{S}$ & & $\mathrm{S}$ & \\
\hline
\end{tabular}

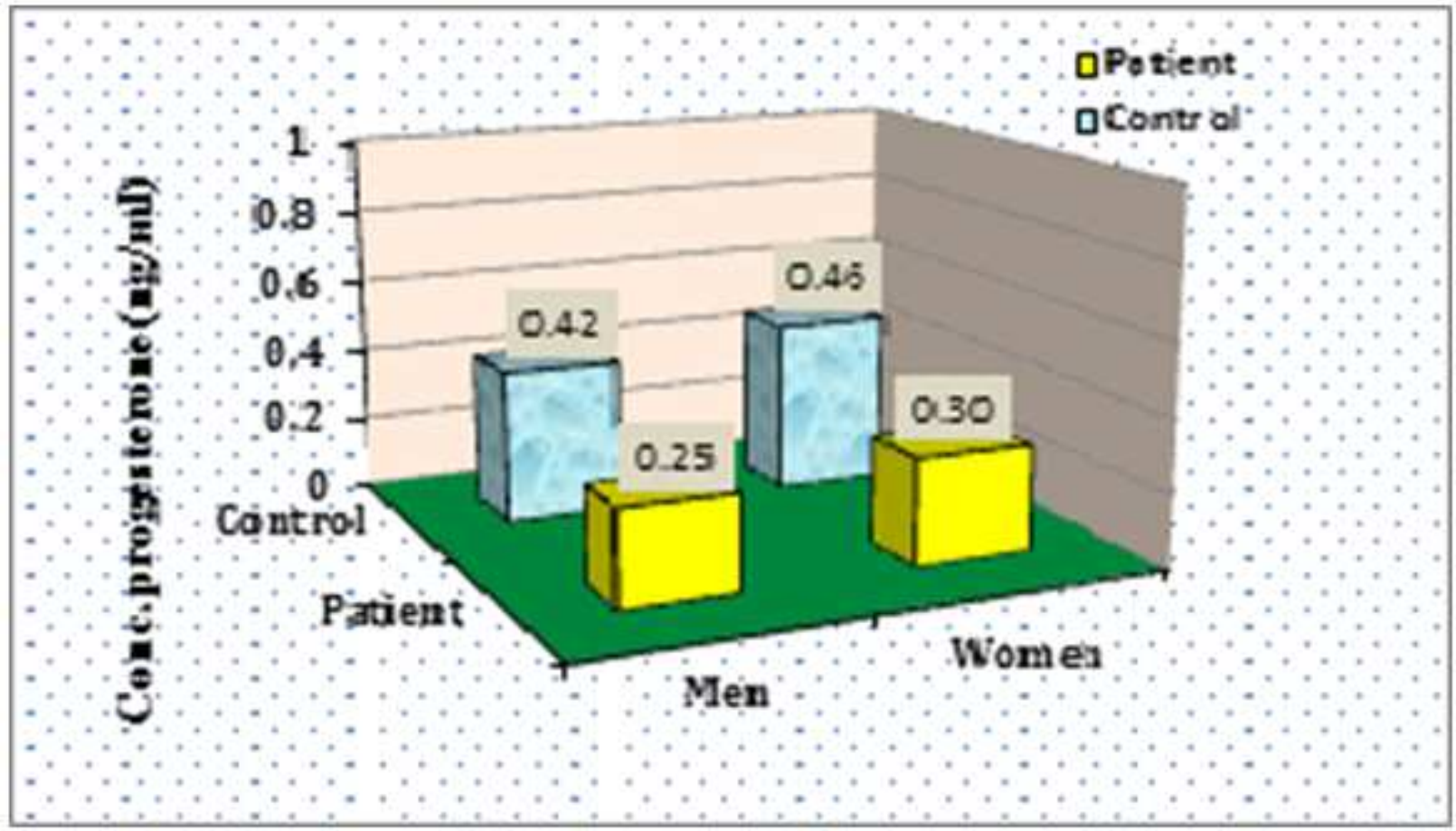

Figure 5. Level of progesterone hormone concentration in serum of healthy control and type 2 diabetic patients.

\subsubsection{Level of Serum Estradiol $\left(E_{2}\right)$ Hormone in Control and Type 2 Diabetic Patients}

Table 8 and Figure 6 reflect the level of serum estradiol $(25.04 \pm 3.35$ Vs. $33.80 \pm 8.4 \mathrm{pg} / \mathrm{ml}$ and $34.33 \pm 4.21$ Vs. $41.42 \pm 5.64$ $\mathrm{ng} / \mathrm{ml}, \mathrm{P}<0.05)$ respectively, in men and women type 2 diabetic patients compared to control.

Table 8. Levels of serum estradiol $\left(E_{2}\right)$ in men and women of control and patients with type 2 diabetes mellitus. The values are the Mean $\pm S D$.

\begin{tabular}{|c|c|c|c|c|c|}
\hline & & \multicolumn{4}{|c|}{ Estradiol (pg/ml) } \\
\hline & & \multicolumn{2}{|l|}{ Men } & \multicolumn{2}{|l|}{ Women } \\
\hline & & $\begin{array}{l}\text { Diabetic } \\
\text { (26) }\end{array}$ & $\begin{array}{l}\text { Control } \\
\text { (25) }\end{array}$ & $\begin{array}{l}\text { Diabetic } \\
\text { (24) }\end{array}$ & $\begin{array}{l}\text { Control } \\
\text { (25) }\end{array}$ \\
\hline \multicolumn{2}{|c|}{ Mean \pm SD } & $25.04 \pm 3.35$ & $33.80 \pm 8.4$ & $34.33 \pm 4.21$ & $41.42 \pm 5.64$ \\
\hline \multicolumn{2}{|c|}{ SE } & 0.65 & 1.41 & 0.86 & 1.45 \\
\hline \multicolumn{2}{|l|}{ Range } & $20.0-31.4$ & $19.2-43.3$ & $25.0--43.6$ & $37.3-58.9$ \\
\hline \multirow{2}{*}{$95 \%$ C.I } & Lower & 18.474 & 17.336 & 26.0784 & 30.3656 \\
\hline & Upper & 31.606 & 50.264 & 42.5816 & 52.4744 \\
\hline \multicolumn{2}{|c|}{ Significance p-value } & $\mathrm{S}$ & & $\mathrm{S}$ & \\
\hline
\end{tabular}




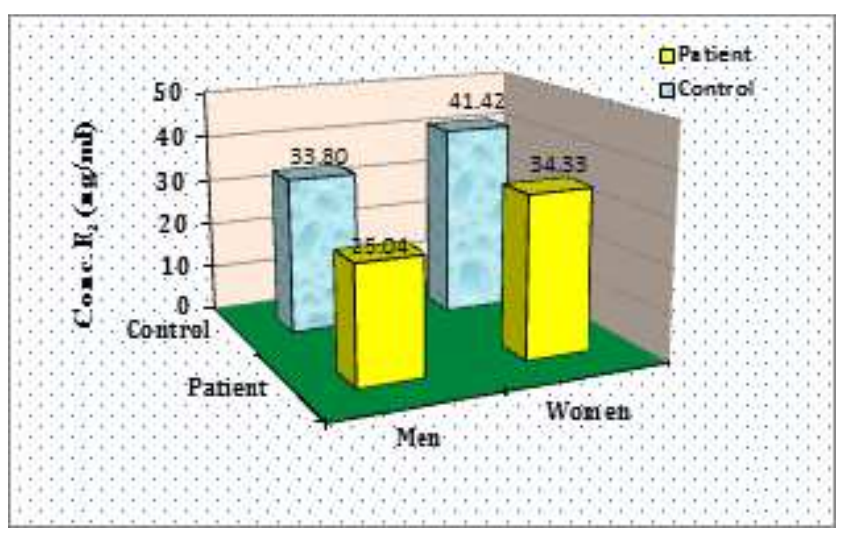

Figure 6. Level of estradiol $\left(E_{2}\right)$ concentration in serum of healthy control and type 2 diabetic patients.

\section{Discussion}

The obesity probably act as a diabetogenic factor, through increasing resistance to the action of insulin, in those genetically predisposed to develop type 2 diabetes; insulin resistance lead to higher plasma levels of insulin, which cause an increase in appetite, so people eat more and put on weight [19]. In the present study it was observed that diabetic patients presented with significantly higher body mass index values compared to controls and there is no significant difference between body mass index values of both patients groups. This constitutes to the notion that obesity may be one of the etiological factors in the development of diabetes mellitus, and mostly as a result of loss of early-phase insulin secretion in response to glucose which occurs relatively early in the development of type 2 diabetes mellitus [20]. This loss is critically important as the early burst of insulin secretion plays an important role in priming target tissues of insulin, especially the liver responsible for normal glucose homeostasis following food uptake; and mealtime glucose excursion (spikes) occur when this process was impaired [21].

The relation between obesity and diabetes was investigated in many studies [22]. These studies showed that obesity is one of the modifiable cardiovascular risk factor that is far more prevalent in those individuals with type 2 diabetes mellitus than in the general population [23]. Moreover, reported that, obesity and physical inactivity are important independent risk factors for type 2 middle aged men. Insulin resistance can be described as a reduced biological response to insulin, primarily to its acute effects on glucose and lipid metabolism. This is pertinent as whether the insulin is produced endogenously or administered exogenously, eventually leading to hyperglycaemia [24]. Pancreatic betacells function may be impaired during adolescence or later on. Its impairment ranges from hyperinsulinemia, secondary to insulin resistance, with normal glucose tolerance to betacells failure with insulin-dependent diabetes mellitus. When insulin resistance is present, or when insulin secretion is diminished in the later stages of the disease, free fatty acids are released in large quantities followed by an increased production of glucose and triglycerides, and secretion of very low density lipoproteins occurs. In addition, free fatty acids also reduce insulin sensitivity in muscles by inhibiting insulin-mediated glucose uptake. On the other hand, increased blood glucose concentration, and to some extent circulating free fatty acids, increase insulin secretion, leading to even more increased hyperinsulinemia. It is obvious that insulin resistance causes blood glucose concentrations and free fatty acids levels to rise, therefore worsening the insulin resistance and, in addition, hyperglycemia with released free fatty acids further increases insulin secretion, forming a vicious circle $[25,26]$. The crucial role of the fat mass does not rule out the importance of heritability in the development of the metabolic syndrome. Environmental factors, i.e. the obesity epidemic due to the lack of physical exercise and increased caloric intake, are obviously responsible for the current increase in the incidence of the metabolic syndrome worldwide. Yet, the predisposition to gain weight is highly individual and to a great extent determined by genetic factors [27]. $\mathrm{t}$ has been hypothesized that triglyceride accumulation in skeletal muscles plays a direct role in the etiology of insulin resistance [28].

The results of some studies have shown that the degree of insulin resistance is positively correlated with intramuscular triglycerides content [29]. According to Poitout and Robertson, chronic hyperglycemia and dyslipidemia in type-2 diabetes mellitus can both produce harmful effects on $\beta$-cell structure and function. Although inter-relationships between glucotoxicity and lipotoxicity have not yet been elucidated, it is presumed that glucotoxicity leading to $\beta$-cell apoptosis occurs independently of dyslipidemia, whereas lipotoxicity additionally damaging $\beta$-cells occurs only in the presence of hyperglycemia. In the case of normoglycemia, elevated free fatty acids should be readily oxidized in the mitochondrion and should not harm the $\beta$-cell [30]. Insulin has been shown to play a central role in the regulation of pituitary and gonadal function. Indeed, insulin enhances luteinizing hormone releasing hormone-induced gonadotrophin secretion in vitro. Reduced glucose utilization by the anterior pituitary cells and a decreased response of follicle stimulating hormone and luteinizing hormone to gonadotropin-releasing hormone administration has been shown in insulin-deficient [31]. Since type 2 diabetes and obesity are associated with hypogondism and since they are both established syndrome of insulin resistance, it possible that insulin resistance itself or the mechanisms underlying it may contribute to this defect. It has recently been suggested that insulin resistance and obesity may be pro-inflammatory states, since obesity is associated with increasing in the expression of tumor necrosis factor- $\alpha$ in adipose tissue and an increase in plasma tumor necrosis factor$\alpha$ and interleukin- 6 concentrations; furthermore, they have an increasing in oxidative damage to lipids, protein and amino acid [32]. The reduced luteinizing hormone and follicle stimulating hormone response to gonadotropin-releasing hormone in diabetic men indicated a decreased acute releasable pool of pituitary gonadotrophins. In diabetic 
women, a reduced luteinizing hormone response to gonadotropin-releasing hormone and alterations in luteinizing hormone secretory activity has been recognized. Furthermore, increased opioidoergic and dopaminergic tones have been hypothesized. Increased central opioid and dopamine have a deleterious effect on reproductive function by acting mainly on the gonadotropin-releasing hormone-luteinizing hormone axis [31].

Also, it has been postulated that diabetes mellitus affect not only insulin level but also causes a marked decrease in luteinizing hormone level. From the other hand, this indicates that there is a relationship between insulin/glucose and luteinizing hormone/follicle stimulating hormone levels in serum, though the mechanisms by which insulin, glucose, or both control these 2 hormones are unclear. Another reason for the findings may be as a result of high oxidative stress generated in diabetic patients who could affect the normal functioning of the pituitary gland and hypothalamus [33]. Decreased level of testosterone is probably the result of a combination of factors, including:

1- Increased abdominal fat, and therefore increased aromatase activity which converts testosterone into estradiol [34].

2- Age-related oxidative damage to testis and Leydig cells, resulting in decreased production of testosterone. Leydig cells are interstitial cells which are interspressed between the seminiferous tubules of the testis. They secrete androgen in response to stimulation by luteinising hormone from the anterior pituitary gland [35].

3- Declining levels of precursor molecules, such as dehydroepiandrosterone. It is produced by the adrenal glands and is the precursor of the sex hormones, estradiol and testosterone.

4- Nutritional status and liver function [35].

5- Decreased of sex hormone binding globulin production, the major carrier protein of testosterone in circulation, is low as a consequence of insulin resistance [36].

Testosterone biosynthesis is regulated primarily by pulsatile secretion of luteinising hormone and serum testosterone levels reflect the integrity of the hypothalamicpituitary-gonadal axis. Therefore low testosterone levels noted in cases of insulin resistance may indicate a defect at one or more functional levels of the hypothalamic-pituitarygonadal axis. In the insulin-resistance state, Leydig cell function, particularly steroidogenesis, may be impaired by changes in the production of hormones and cytokines locally in the target tissue and in adipose tissue [37]. Although several studies suggest that increasing insulin resistance may be attributed to a decrease in testosterone secretion in men, it is not fully clear how the hypothalamic-pituitary-gonadal axis mediates the interplay between testosterone and insulin levels. Other potential mechanisms for low testosterone levels in type 2 diabetes mellitus include reduced or absent stimulatory effect of insulin on Leydig cells, increased leptin levels in diabetes causing Leydig cell dysfunction 8 , incresed tumor necrosis factor levels in diabetes inhibiting steroid biosynthesis in Leydig cells. Clearly, additional studies are needed to fully delineate the biochemical and physiological mechanisms underlying reduced testosterone synthesis in diabetes [34].

Decreased level of progesterone in diabetic patients might be due to the high concentrations of glucose through inhibition the ratio $(1 / 2)$ of mitogen-activated protein kinase to extracellular signal-regulated kinase which is leading to a reduction in the 3- $\beta$-hydroxysteroid dehydrogenase level and consequently progesterone secretion [38]. Some studies suggest that oxidative stress plays a role in the etiology of adverse reproductive events in both women and men [39]. Oxidative stress occurs from an imbalance between reactive oxygen species and antioxidant actions. Furthermore, diabetes has marked effects on normal cellular processes, resulting in dysregulated mitochondrial free radical production and disparity between reactive oxygen species generation and antioxidant defenses, leading to diminished gonadotrophin and anti-steroidogenic actions, DNA damage, and inhibited protein ATP production. Thus the diminished levels of both gonadotrophins (luteinizing hormone and follicle stimulating hormone) and the steroids (estradiol and progesterone) may be attributed to increased reactive oxygen species generation [40]. One of the possible mechanisms for the decline in levels of estradiol in diabetic patients may be related to reduce levels of testosterone and thus lack of substrate for aromatization to estradiol. In addition, reduced aromatase activity may also contribute to reduced estradiol synthesis [41]. Indeed, a mutation in the aromatase gene, resulting in aromatase deficiency, was first identified in a man with type 2 diabetes [42].

On the other hand, one developing theory of insulin resistance is that chronic oxidative stress activates kinases such as cJun-N-terminal Kinase and interleukin kappa Bkinase $\beta$, which inhibit activation of the insulin signaling intermediates [43]. Estradiol suppresses oxidative stress likely via both nongenomic and genomic actions [44], by activating pathways that prevent generation of reactive oxygen species and increasing efficient scavenging of reactive oxygen species. It is also likely that some of the effects of loss of estradiol on insulin action are due to the increased adiposity associated with estradiol-deficiency. Both estradiol receptor $(\alpha-)$ and G-Protein coupled estradiol receptor 1 deficient have increased adiposity and insulin resistance [45].

\section{Conclusion}

In conclusion, the work performed in this study confirmed that insulin resistance plays an important role in the pathogenesis of many human diseases, such as diabetes, obesity, and reduction of fertility. Therefore, the associated of obesity and increased insulin resistance is accompanied by low levels of follicle stimulating hormone, luteinizing hormone, testosterone, progesterone and estradiol in both men and women type 2 diabetic patients. The discussion of these theories is beyond the scope of our study; suffice it to say that the underlying basis for the sex difference in risk 
from diabetes remains, for the most part, speculative.

\section{References}

[1] David G, Gardner and Dolores. Greenspan's basic \& clinical endocrinology (9th ed.). New York: McGraw-Hill Medical. 2011.

[2] Craig ME, Hattersley A and Donaghue KC. Definition, epidemiology and classification of diabetes in children and adolescents. Pediatric diabetes. 2009; 10: 3-12.

[3] Shepherd PR and Kahn BB. Glucose transporters and insulin action: Implications for insulin resistance and diabetes mellitus. N. Engl. J. Med. 1999; 341(4): 248-257.

[4] Zimmet P Alberti KG and Shaw J. Global and societal implications of the diabetes epidemic; Nature (London). 2001; 414: 782-787.

[5] Saltiel AR and Kahn CR. Insulin signalling and the regulation of glucose and lipid metabolism. Nature. 2001; 414: 799-806.

[6] Bak JF, Moller N, Schmitz O, Saaek A and Pedersen O. In vivo insulin action and muscle glycogen synthase activity in type 2 (non-insulin-dependent) diabetes mellitus: Effects of diet treatment. Diabetologia. 1992; 35: 777-784.

[7] Tsai EC, Matsumoto AM, Fujimoto WY and Boyko EJ. Association of bioavailable, free, and total testosterone with insulin resistance: influence of sex hormone-binding globulin and body fat. Diabetes Care. 2004; 27: 861-868.

[8] Isidori AM, Caprio M, Strollo F, Moretti C, Frajese G, Isidori $\mathrm{A}$ and Fabbri A. Leptin and androgens in male obesity: Evidence for leptin contribution to reduced androgen levels. J Clin Endocrinol Metab. 1999; 84: 3673-3680.

[9] Teerds KJ, de Rooij DG and Keijer J. Functional relationship between obesity and male reproduction: from humans to animal models. Hum Reprod Update. 2011; 17: 667-683.

[10] Giagulli VA, Kaufman JM and Vermeulen A. Pathogenesis of the decreased androgen levels in obese men. J Clin Endocrinol Metab. 1994; 79: 997-1000.

[11] Trinder P. Determination of glucose in blood using glucose oxidase with an alternative oxygen receptor, Ann. Clin. Biochem. 1969; 6: 24-27.

[12] Judzewitsch RG, Pfeifer MA, Best JD, Beard JC, Helter JB and Porte DJ. Chronic Chlorpropamide therapy of noninsulindependent augments basal and stimulated insulin secretion islet sensitivity to glucose. J. Clin. End. Metab. 1982; 55(2): 321-328.

[13] Yalow RS and Berson S A. Principles of Competitive ProteinBinding Assays (Odell, W. D. \& Daughaday, W. H., eds.), Lippincott, Philadelphia. 1971; pp: 1- 21.

[14] Odell WD, Parlow AF. Estimation of FSH Test Assay. Journal of Clinical Investigation. 1981; 47: 25-51.

[15] Kosase TS. Measurement of human luteinizing hormone. J. Reprod. Med. 1981; 26: 201-206.

[16] Kicklighter EJ and Norman RJ. The Gonads. J. Clin. Chem. 1989; 43: 658-660.

[17] Hahlin M, Wallin A, Sjöblom P and Lindblom B. Single
Progesterone Assay for Early Recognition of Abnormal Pregnancy. Hum Reprod. 1990; 5(5): 22-626.

[18] Wramsby H, Sundstrom P and Liedholm P. Pregnancy rate in relation to number of cleaved eggs replaced after in-vitro fertilization in stimulated cycles monitored by serum levels of oestradiol and progesterone as sole index. Human Reproduction. 1987; 2: 325-328.

[19] Edwards CRW, Baird FD and Toft AD. Endocrine and metabolic disease. In: Davidson's principles and practice of medicine. A textbook for students and doctors. Edwards CRW, Bouchier IDA. $16^{\text {th }}$ edition. Churchil Livingstone, Hong Kong. 1991: 607-698.

[20] Ward WK, Beard JC, Halter JB, Pfeifer MA and Porte D. Pathophysiology of insulin secretion in non-insulin-dependent diabetes mellitus. Diabetes Care. 1984; 7: 491-502.

[21] Bruttomesso D, Pianta A and Mari A. Restoration of early rise in plasma insulin levels improves the glucose tolerance of type 2 diabetic patients. Diabetes. 1999; 48: 99-105.

[22] Knowler WC, Pettitt DJ, Savage PT and Bennett PH. Diabetes incidence in Pina Indians: contribution of obesity and parental diabetes. Amer. J. Epidemiol. 1981; 113(2): 144-156.

[23] Perry IJ, Wannamethee SG, Walker MK, Thomson AG, Whincup PH and Shaper AG. Prospective study of risk factors for development of non-insulin dependent diabetes in middle aged British men. B M J. 1995; 310: 560-564.

[24] Ruan H and Lodish HF. Regulation of insulin sensitivity by adipose tissue-derived hormones and infl ammatory cytokines. Curr Opin Lipidol. 2004; 15: 297-302.

[25] McGarry JD. Dysregulation of fatty acid metabolism in the etiology of Type 2 diabetes. Diabetes. 2001; 5: 7-18.

[26] Pan DA, Lillioja S and Kriketos AD. Skeletal muscle triglyceride levels are inversely related to insulin action. Diabetes. 1997: 983-988.

[27] Speakman JR. Obesity: the integrated roles of environment and genetics. J Nutr. 2004; 134: 2090-2105.

[28] Fruchart JC, Sacks F, Hermans MP, Assmann G, Brown V, Ceska R, Chapman MJ, Dodson PM, Fioretto P, Ginsberg HN, Kadowaki T, Lablanche JM, Marx N, Plutzky J, Reiner Z, Rosenson RS, Staels B, Stock JK, Sy R, Wanner C, Zambon A and Zimmet P. Executive statement: The Residual Risk Reduction Initiative: A call to action to reduce residual vascular risk in dyslipidemic patients A condensed position paper by the Residual Risk Reduction Initiative $\left(\mathrm{R}^{3} \mathrm{i}\right)$. Diab Vasc Dis Res. 2008; 5: 319-333.

[29] Poitout V and Robertson RP. Minireview: Secondary beta-cell failure in type 2 diabetes- a convergence of glucotoxicity and lipotoxicity. Endocrinology. 2002; 143: 339-342.

[30] Colhoun HM, Betteridge DJ and Durrington PN. Primary prevention of cardiovascular disease with atorvastatin in Type 2 diabetes in the Collaborative Atorvastatin Diabetes Study (CARDS): multicentre randomised placebo-controlled trial. Lancet. 2004; 364(9435): 685-696.

[31] Baccetti B, la Marc A, Piomboni P, Capitani S, Bruni E, Felice Petraglia F and De Leo V. Insulin-dependent diabetes in men is associated with hypothalamo-pituitary derangement and with impairment in semen quality. Human Reproduction. 2002; 17(10): 2673-2677. 
[32] Hussein Z and Al-Qaisi J. Effect of diabetes mellitus type 2 on pituitary gland hormones (FSH, LH) in men and women in Iraq. J. Al-Nahr. Univer., Science. 2012; 15(3): 75-79.

[33] Onah CE, Meludu SC, Dioka CE, Onuegbu JA, Amah UK, Olisekodiaka MJ, Okwara JE, Onah CF and Ezeugwunne IP. Pattern of male sex horones in type 2 diabetic patient in Nnewi, South Eastern Nigeria. 2013; 10(4): 65-70.

[34] Verma S, Saxena S, Kushwaha JS, Giri R, Priyadarshi BP and Singh P. Serum testosterone levels in type 2 diabetes mellitus. JIACM. 2013; 14(2): 115-118.

[35] Dhindsa S, Prabhakar S, Seth M, Bandyopadhyay A, Chaudhuri A and Dandona P. Frequent Occurrence of Hypogonadotropic Hypogonadism in Type 2 Diabetes. J. Clin. Endoc. Metab. 2004; 89(11): 5462-5468.

[36] Esmaeel AK. Relationships between diabetes mellitus type 2 and male testosterone level. 2013; 21(1): 56-62.

[37] Ballester J, Muñoz MC, Domínguez J, Rigau T, Guinovart JJ and Rodríguez-Gil JE. Insulin-Dependent Diabetes Affects Testicular Function by FSH- and LH-Linked Mechanisms. J. 2004; 25(5): 706-719.

[38] Simard J, Ricketts ML, Gingras S, Soucy P, Feltus FA and Melner MH. Molecular biology of the 3 eta-hydroxysteroid dehydrogenase/delta5-delta4 isomerase gene family. Endocr. Rev. 2005; 26(4): 525-582.

[39] Acevedo CG, Carrasco G, Burotto M, Ro-Jas S and Bravo I. Ethanol inhibits L-arginine uptake and enhances NO formation in human placenta. Life Sci. 2001; 68: 2893-2903.
[40] Khowailed A, Mohammad O, Elattar S and Gaber S. Effect of Sildenafil on gonadotrophin and sex steroids in fructose induced diabetes in female rats. Med. J. Cairo Univ. 2012; 80(2): 243-252.

[41] Maric C, Forsblom C, Thorn L, Johan Wadén J and Groop P. Association between testosterone, estradiol and sex hormone binding globulin levels in men with type 1 diabetes with nephropathy. Steroids. 2010; 75(11): 772-778.

[42] Maffeim L, Muratam Y, Rochira V, Tubert G, Aranda C, Vazquez M, Clyne CD, Davis S, Simpson ER and Carani C. Dysmetabolic syndrome in a man with a novel mutation of the aromatase gene effects of testosterone, alendronate, and estradiol treatment. J Clin Endocrinol Metab. 2004; 89: 61-70.

[43] $\mathrm{Li} \mathrm{H}$ and $\mathrm{Yu} \mathrm{X}$. Emerging role of JNK in insulin resistance. Current Diabetes Reviews. 2013; 9(5): 422-428.

[44] Lopez-Grueso R, Gambini J, Abdelaziz KM, Monleon D, Diaz A, El-Alami M, Bonet-Costa V, Borras C and Vina J. Early, but not late onset estrogen replacement therapy prevents oxidative stress and metabolic alterations caused by ovariectomy. Antioxid. Redox Signal. 2014; 20: 236-246.

[45] Haas E, Bhattacharya I, Brailoiu E, Damjanovic M, Brailoiu GC, Gao X, Mueller-Guerre L, Marjon NA, Gut A, Minotti R, Meyer MR, Amann K, Ammann E, Perez-Dominguez A, Genoni M, Clegg DJ, Dun NJ, Resta TC, Prossnitz ER, Barton M. Regulatory role of $\mathrm{G}$ protein-coupled estrogen receptor for vascular function and obesity. Circ Res. 2009; 104: 288-291. 